\title{
ALPINE EUROPE
}

by

Jacques Debelmas

Formed from sediments accumulated in a branch of the Tethys between the Eurasian and African continents, the mountain chains of Alpine Europe may be divided into three major segments: the Pyrenees, which resemble an intracratonic chain but which originated in the transform zone on the northern edge of the Iberian craton; the "geosynclinal" chains - amongst the most sinuous and heterogeneous in the world; and the Aegean and Tyrrhenian arcs which exhibit a curious "CircumPacific" aspect lacking elsewhere in the Alps.

\section{The Pyrenees}

This chain originated in an early Cretaceous rift - the North Pyrenean zone - which was subsequently closed. It was subjected to thermal metamorphism in Cretaceous time, and later to high pressure metamorphism toward the end of the Cretaceous.

Those who accept the rift concept still disagree over the extent of the transform movement between the two margins of the rift. Some argue that there is little or no translation because palaeogeographic boundaries seem to extend without interruption on either side of the existing chain. Others feel that there was considerable displacement corresponding to the movement of the Iberian craton that followed the opening of the Bay of Biscay; hence, the North Pyrenean zone should be regarded as a true "transform zone". If one accepts the second hypothesis, it makes the Pyrenees a rather unique chain.

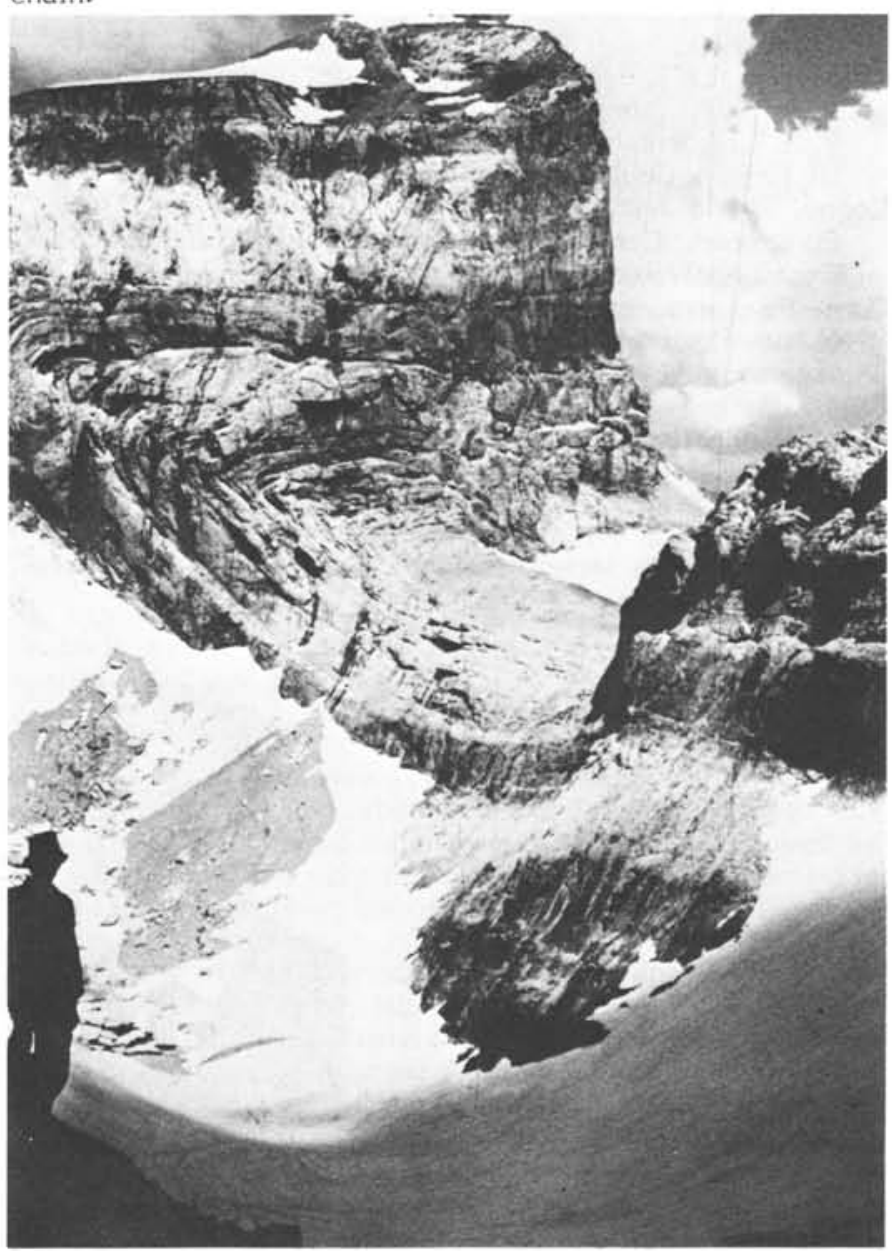

View of Cylindro (el Cilindro), Pyrenees, Spain. A northward closing syncline of Eocene carbonates overlies the obvious anticline of Paleocene strata. The summit of the mountain is formed by an allochthonous block of Maastrichtian (Upper Cretaceous). (Photo courtesy W.C. Morgan)

\section{The Geosynclinal Axis}

This Axis was formed as a result of the movement and eventual collision of two stable blocks - Europe and Africa. These movements were complicated by the existence of salients in the margins of each block: the Apulo-Adriatic promontory (Fig. 1) of the African craton (which played an important role in the genesis of the Alpine arc), and the Moesic promontory (Fig. 2) of the European craton (which influenced the formation of the Carpathian arc and the Balkan massif).

The Geosynclinal Axis itself is of opposing vergence with (i) an Alpidic branch on the edge of the European craton, overturned toward it, comprising the Betic chains, Corsica, the Alps, the Carpathians and the Balkan massif, and (ii) a Dinaric branch on the edge of the African craton, overturned toward it, comprising the North African chains (or Maghrebides), the Sicilian-Calabrian arc, the Appennines, the Dinarides and the Hellenides.

In each of these branches one can distinguish external zones (externides), a deformed part of the foreland affected only by late phases of folding (late Eocene to Neogene), and internal zones (or internides), separated from the externides by an important palaeogeographic and structural discontinuity, the appearance of which demonstrates the "Mesogean Jurassic stretching". Later, this discontinuity behaved as a zone of lateral movement or thrusting. On its internal side, in Jurassic time, there were intensely fractured areas which resulted from stretching under tension; the crust was thin and some strips of it were neo-oceanic.

This broad strain pattern was greatly reduced in some places from late Jurassic on, in others from about late Cretaceous on. The probable subduction of neo-oceanic crustal fragments led to the complex phenomena of overthrusting and high-pressure metamorphism.

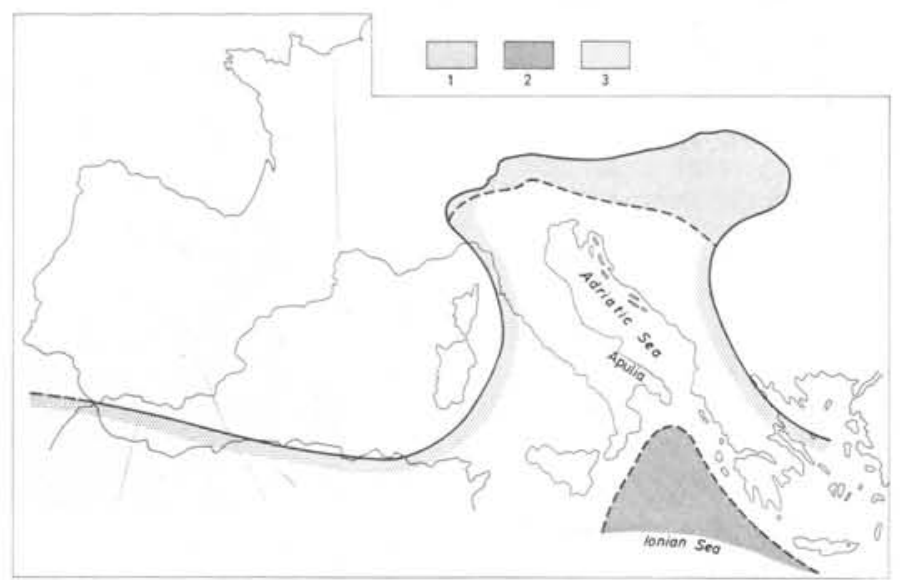

Figure 1. The Apulo-Adriatic promontory of the African plate. 1: The overriding frontal portion (Austroalpine zone); 2: Zone of crustal thinning (Ionian sea); 3: Approximate limit of former African continent. 


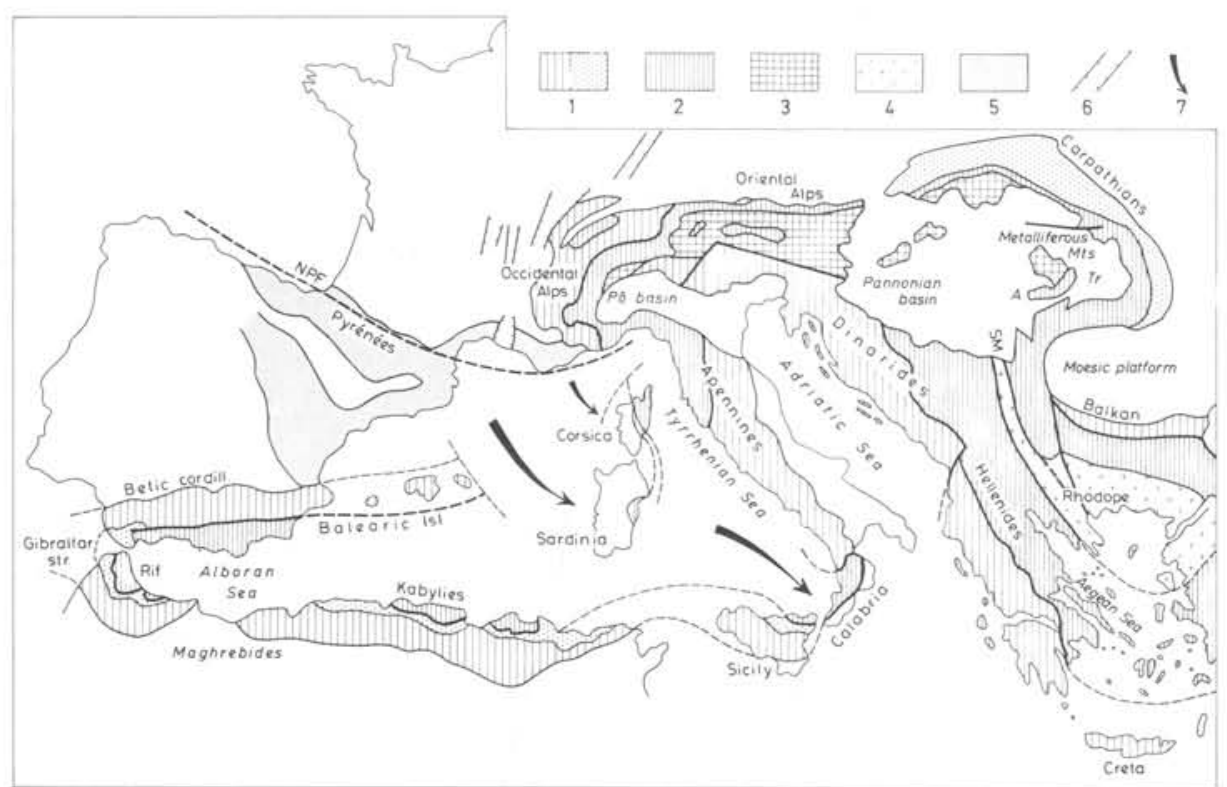

Figure 2. The chains of Alpine Europe. 1: Externides (lines: mainly of Mesozoic material; dots: mainly of flysch material); 2: Internides; 3: Austroalpine zone; 4: Rhodope microcraton; 5: Intracontinental chains; 6: Rifts; 7: Continental displacements and sphenochasms (A: Apuseni Mountains; NPF: North Pyrenean fault; SM: Serbo-Macedonian massif; Tr: Transylvanian basin).

\section{Alpidic Branch}

\section{Alpidic Externides}

The Betic chains (Fig. 2) comprise the Prebetic zone, nearest to the foreland cover, and a Subbetic zone which is entirely allochthonous. The Prebetic zone extends as far east as the Balearic islands, beyond which the continuity of the external Alpidic chain is broken by the recent opening of the AlgeriaProvence gulf, associated with the sinistral rotation of the Corsica-Sardinia axis. The zone is scarcely represented in Sardinia and Corsica (the Corte slivers), but is seen again in the French subalpine chains (Occidental Alps - Fig. 2). These are flanked on the east by massive crystalline slivers ("external crystalline massifs"), covered mainly by Jurassic rocks.

In approaching the zone of hypercollision in Switzerland, the compression of externides becomes more intense, giving rise to the Helvetic and Ultrahelvetic nappes. In Austria, hypercollision is at its maximum, with externides reduced to minute slivers riding on the front of the nappes that are of a more southerly origin (Fig. 1).

Externides of a different nature are seen over a wide area in the Carpathians. Here, the zone of separation between externides and internides must have been one of crustal

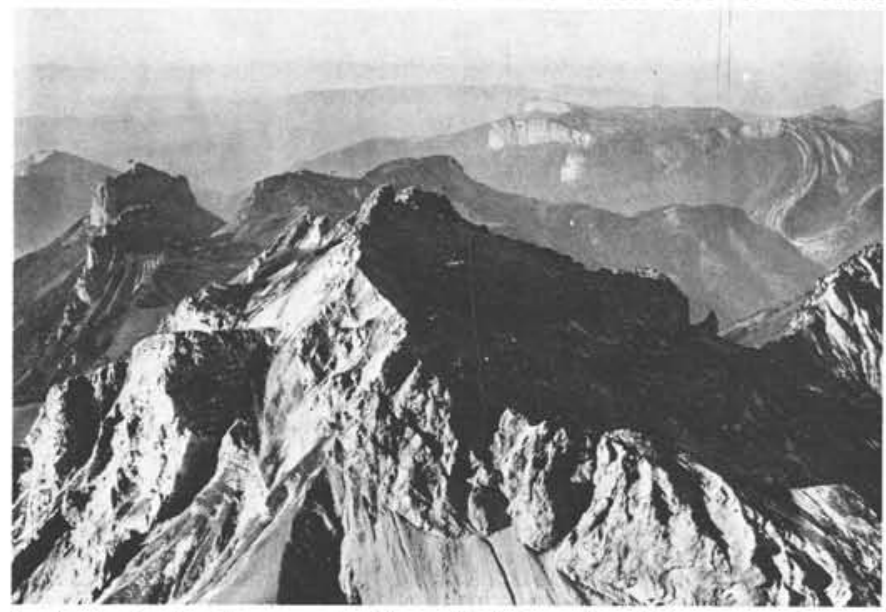

A typical landscape in the Alpine externides: the Bornes massif (French Subalpine ranges). Foreground: La Tournette massif; background: Parmelan plateau and Glières syncline; all relief is in Urgonian limestones. This is a Mesozoic platform sequence in which the calcareous horizons control the morphology and clearly outline folds. thinning, which acted, during compression, as a true intracontinental subduction zone in which most of the outer crust disappeared, leaving only the highest strata of the cover; these were detached and formed the flysch nappes (zone of the Moldavian nappes). Existence of an andesitic arc of Neogene age, in the north of the Pannonian basin (Fig. 3), and the initial thinning of the sub-Pannonian crust, an abortive marginal basin, provide evidence for this subduction zone.

Alpidic externides end in the Balkan massif with the Prebalkan, which appears as the deformed southern extremity of the Moesic platform.

In summary, Alpidic externides comprise parts of the foreland and its cover, which is generally detached at the level of the Triassic evaporites. They also include an intracratonic

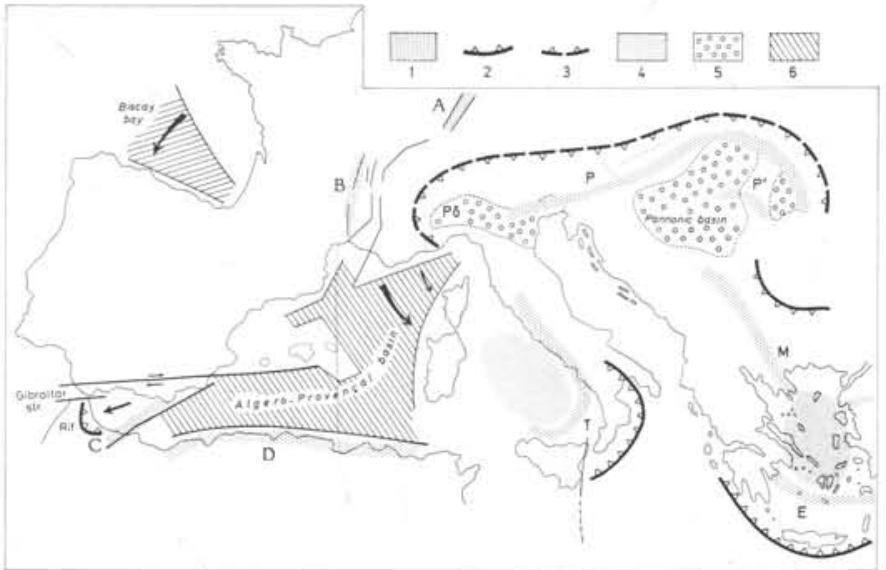

Figure 3. Major neotectonic features of Alpine Europe. 1: Volcanic arcs (A: Rhine trench; B: French Massif Central; C: Alboran sea; D: North Africa; E: Aegean arc; M: Macedonian arc; $P$ and $P^{\prime}$ : Pannonian arcs; T: Tyrrhenian arc); 2: Subduction zones (E: Aegean; T: Tyrrhenian); 3: Intracontinental subduction zones of the Alpine and Carpathian externides; 4: Marginal basin or zone of crustal thinning; 5: Intramontane molassic basin; 6: "Neo-oceanic" gulfs of Algeria-Provence and the Bay of Biscay with indications of the corresponding continental opening movements. 
zone of subduction in which the basement of part of the foreland disappears, so that its cover becomes allochthonous. This makes tenable the hypothesis that the passage from externides to internides must have been a zone of crustal thinning or a rift.

The same contrast is found in sedimentary facies, with thin, mainly calcareous, neritic deposits toward the exterior, and more clayey deposits, typical of subsiding areas and deeper water, toward the interior (Subbetic, Ultrahelvetic and Moldavian series). The flysch facies may have been developed either in the Upper Jurassic-Lower Cretaceous (as in the Carpathians and the Preba!kan) or only in the Eocene (Ultrahelvetic). This strongly suggests the existence of a synorogenic trench developing ahead of a group of more interior nappes in the course of construction.

\section{Alpidic Internides}

Betic zones of the southern Spanish chains are made up of a number of units, each with Palaeozoic or granito-gneissic basement and a thin, mainly calcareous cover. While ophiolitic units are not found there, they do form the main part of the internides of Corsica, framed by slivers representing the ancient margins of a neo-oceanic trough.

In the Alps, both units coexist. The main part of the ophiolite-bearing units forms the Piemontese zone s.l. (or zone of "schistes lustrés"), the corresponding palaeogeographic province having probably tapered out toward the east. To the north, ophiolite-bearing units also appear locally in the Valais zone.

These two troughs thus enclose a sort of sialic microcraton, the Briançon zone (called the "Great St. Bernard nappe" by Swiss geologists). The European origin of this structure is obvious in the French Alps, where the Valais zone pinches out to the west. This complex of units, sometimes collectively called the Penninic group, then disappears to the east beneath the great Austroalpine thrust (the distorted margin of the Apulo-Adriatic promontory of the African craton), and reappears in the western Dacides near the Carpathians.

The continuation of (or the successor to) the Penninic is thus found again in front of the Dacides in the Pienides, but without ophiolitic units. Its overthrust character is also less pronounced because it lies to the east of the axis of the east Alpine hypercollision. Ophiolitic units do occur in what is probably the continuation of the Pienides in the Apuseni
Mountains to the south of the Metalliferous Mountains (Fig. 2).

In the eastern Carpathians, the structure becomes complicated once again by two ophiolite-bearing zones, although there is no evidence to confirm correlation with the Valais and Piemont troughs. These two zones are the Transylvanian ophiolitic nappes (the continuation of the ophiolitic zones of the Apuseni Mountains), representing the external Dacic megatrough), and the more external ophiolite-bearing units (the Ceahlau and Severin nappes), representing the external Dacic megatrough.

The remaining units of the eastern and southern Dacides between these two zones suggest a microcraton reminiscent of the Briançon zone in the western Alps. This element is the only one in the Balkan massif where ophiolitic units are lacking, as in the Betic chains at the western end of the European Alpine chain. Late Cretaceous vulcanism and "Laramic" granites, however, constitute a new feature.

In the European Alpidic arc, troughs with oceanic crust appear beyond the Betic sector, in Corsica. They are strongly developed in the Alps, but appear "sealed" in the Carpathians and especially in the Balkan massif. It is interesting to note that the maximum development of oceanic crust corresponds to the most strongly arched and over thrust belts in the European Alpidic system.

The history of the internides is complex. In Triassic time, a carbonate platform was established on a sialic basement. This platform was broken up at the end of the Triassic and in the Lias. Troughs with neo-oceanic crust then rapidly appeared during the "Mesogean Jurassic stretching", to be consumed by subduction from the end of the Lower Cretaceous (for the Piemont and internal Dacic troughs), or the Upper Cretaceous (for the Valais and external Dacic troughs). The first phase of tectonism led to widespread high-pressure metamorphism at around $80 \mathrm{Ma}$.

Thus, by the end of the Upper Cretaceous, the construction of the internal Penninic, the Austrides and Dacides was well advanced. A new and even more widespread tectonic phase started at the end of the Eocene ( $39 \mathrm{Ma}$ ), locally accompanied by high pressure metamorphism.

Two observations emanate from this history: (i) the tectonic phases corresponded to periods of acceleration of Atlantic spreading, and of collision between the European and African masses; and (ii) subductions which sealed the oceanic troughs

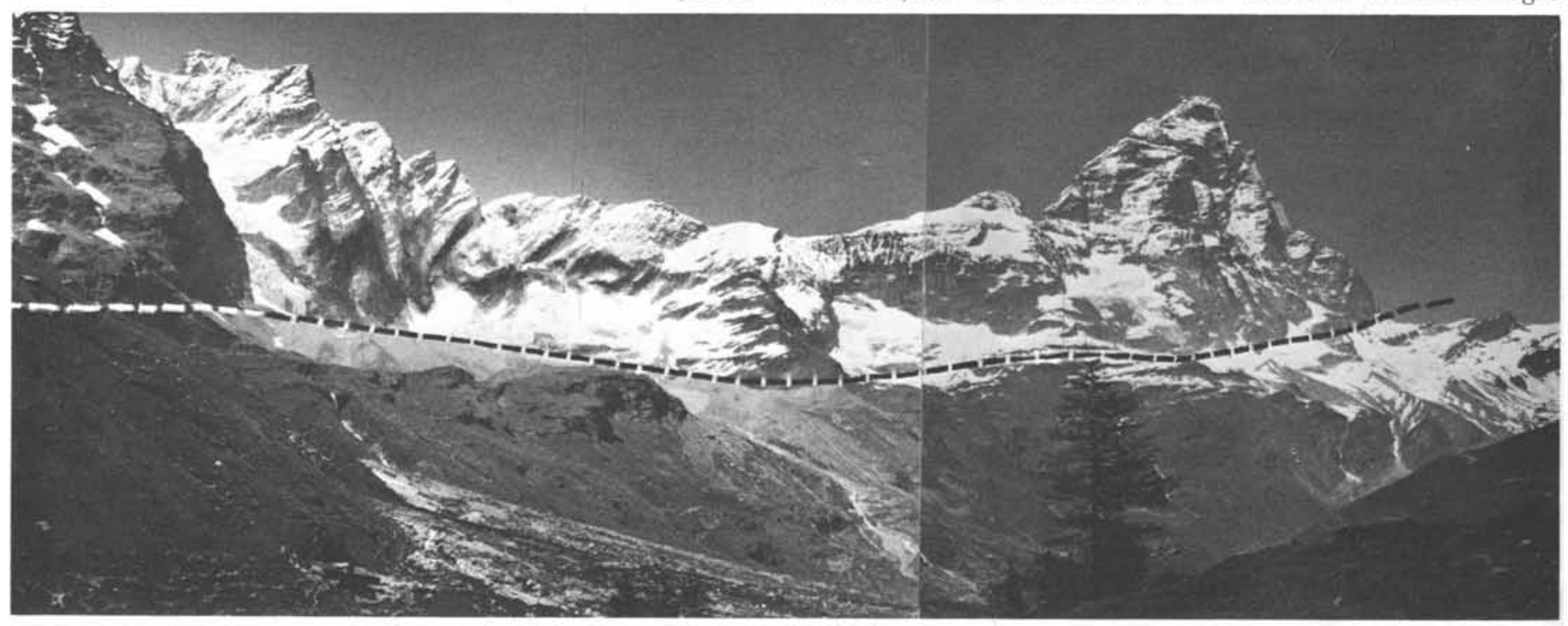

A typical landscape of the Alpine internides: looking north toward the Cervin (Matterhorn) from the Valtournache (Italy). The Cervin and the snow-covered mountains to its left belong to the old Paleozoic or Precambrian Austroalpine Crystallines, which here form part of the Dent Blanche nappe, thrust northward (along dotted line). The bottom of the valley (below the thrust) is formed of "Piemont schistes lustres" (metamorphozed, ophiolite-bearing complex), strongly deformed as a result of a polyphase tectonic history. In terms of plate tectonics, the Cervin represents the continental African margin, thrust over the relicts of the oceanic Alpine (Tethyan) realm. 


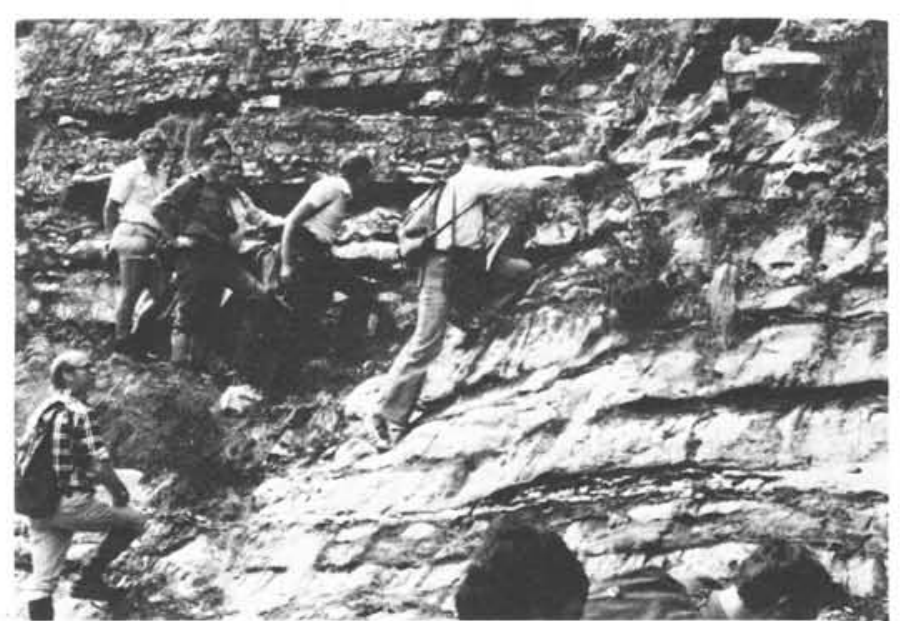

Middle Triassic bedded limestone containing Anisian ammonites, Val Camonica, northern Italy. (Photo courtesy E.T. Tozer)

did not have associated vulcanism or granitization as far east as the eastern Carpathians and the Balkan massif: here late Cretaceous "banatite arcs" may be linked with the subduction at the external Dacic megatrough. The reason for the lack of magmatism along much of the Alpidic branch is not yet clear.

\section{Dinaric Branch}

\section{Dinaric Externides}

Dinaric externides begin in North Africa with the external zones of the Rif and the Tell, which correspond to a subsiding area on the northern edge of the Sahara foreland where the cover was thinner and more neritic. The Rif-Tell sedimentary material, detached at the level of Triassic gypsums, forms nappes with southern vergence. Beneath them, parautochthonous units show transition facies to those of the Sahara foreland.

The Tell trough disappears beneath the Mediterranean, west of Tunis. It is interrupted by the recent structures of the Tyrrhenian sea, but is recognizable again in the Appennines of Marche, Umbria and Tuscany, where it is allochthonous to parautochthonous, and its foreland corresponds to the whole of southern Italy. The Abruzzi Campania mark the transition, as in the Tell, to Apulia, the Pouilles and the Ragusa plateau in Sicily - equivalents of the Saharan platform.

In the southern Alps (Bergamo Alps, Trentino, Friuli), external zones form a curve enveloping the extremity of the Apulo-Adriatic salient. The "miogeosynclinal" character of the trough becomes obscured here by the appearance of ridges and troughs that complicate the palaeogeography.

The allochthonous nature of the externides is also obscured: at most, the Mesozoic cover shows some superficial folds with southward vergence. But, on the other side of the periAdriatic line of fracture, this same material becomes the Austroalpine zone which overrides strongly toward the north. This peri-Adriatic fracture belt (its course marked by Oligocene granites) thus marks the limit, within the African margin, between autochthonous material of southward vergence and that of northward vergence. At depth it should also correspond to the southern limit of overthrust Penninic material.

In the Yugoslav Dinarides, externides form the Dalmation coast and the Karstic zone, sedimentation being of the neritic or reef type. It is only in the Hellenides that troughs of truly pelagic deposition reappear in the heart of this epicontinental calcareous complex (the zones of lonia, the Pindus and Boeotia, separated by the Gavrovo and Parnassus ridges). Hellenic externides form the Pelopponese and Crete. Their tectonic style is that of thick thrust slices (in the
Dalmation zone) or of folds with southwestern vergence (in the Ionian zone), all emplaced in the Neogene.

\section{Dinaric Internides}

From West to East, the Dinaric internides are represented first by a narrow North African fringe - the massifs of the Rif, where Betic units recur (the Betic-Rif arc raises the problem of linking the Dinaric and Alpidic branches), the Kabyle massifs of Algeria, the Peloritan massif of Sicily, and the Sila massif in Calabria. All of these are allochthonous, with a sialic basement and a dominantly calcareous cover overriding allochthonous Cretaceous-to-Palaeogene flysch whose palaeogeographic origins are not always clear. Deformation everywhere is prior to Upper Oligocene; Lower Miocene deposits unconformably overlie these eroded early Tertiary structures.

In the first group of massifs, the ophiolite-bearing units are lacking, as in the corresponding sector of the Alpidic branch. They are present in the Ligurian Appennines, where they form an allochthonous complex with eastward vergence, thrust over the Tuscan units. The deposits are identical to those of Corsica and the Penninic Alps, the Upper Jurassic radiolarites being in direct contact with the oceanic crust. There was thus only a single basin (the Piemont-Liguria basin); the eastward displacement of the Ligurian nappe over the external Appennine sector is a late feature of intraOligocene age. The Ligurian nappes and their foundations were then carried en bloc northeast in the Neogene, probably in association with the sinistral rotation of the CorsicaSardinia axis (Figs. 2 and 3).

The ophiolite-bearing units are interrupted at the northern extremity of the Apulo-Adriatic spur: they pass beneath it and become confused with those of the Alpine Penninic and, like them, they disappear beneath the slab of the eastern Alps. They reappear east of the Adriatic in the internal Dinarides, where they are thrust over the externides (in the Serbian nappe), and then, further south, form two zones in the Hellenides which enclose the Pelagonian zone.

The northeastern (Vardar) zone is a continuation of the Yugoslav belt; the southwestern (sub-Pelagonian or Maliac zone is either a supplementary suture closing to the northwest, or a late (and frontal) fragment pinched off an ophiolitic nappe coming from the Vardar. If this latter hypothesis is accepted, it follows that the Vardar trough is the only single oceanic trough in the whole of the Dinaric and Hellenic system. The very extensive and intense synsedimentary vulcanism in the Upper Triassic (spilite-keratophyre type) and Upper Jurassic (potassic rhyolite type) adds complexity to the reconstruction of the palaeogeography. There was even andesitic to basaltic volcanism in the Oligo-Miocene in the Macedonian arc (Fig. 3), the significance of which is still obscure.

The Vardar zone is bounded to the east by the SerboMacedonian and Rhodope massifs (Fig. 2), both of which are partly sheared. They appear to be a crushed microcraton separating the Alpidic and Dinaric branches.

The internal Hellenic zones disappear beneath the Aegean sea, reappearing only in the Cyclades archipelago where the most southerly islands have become a true volcanic arc as a result of subduction, still in progress today.

To summarize, internides of the Dinaric branch comprise two quite different sectors: the Western Mediterranean, in which the oceanic portion is not easily distinguished from that of the Alpidic branch. Formed in the Middle or at the beginning of the Upper Jurassic and closed by subduction during the Upper Cretaceous, this sector had no accompanying vulcanism on its immediate borders. The Eastern Mediterranean sector, in which the oceanic portion (whether divided into two or not) is separated from that of the Alpidic branch by the Serbo-Macedonian and Rhodope microcraton, appeared earlier than in the Upper Triassic and disappeared in the 
Upper Jurassic, accompanied by intense vulcanism.

\section{Gibraltar Arc}

The two European branches of the Alpine system seem to come together in the Gibraltar arc in a way that has given rise to two interpretations. The arc is thought by some to be inherited from an originally arcuate palaeogeographic distribution, suggested by similarities between the Betic and Rif internal units, which became separated by the Straits of Gibraltar only in the Pliocene. This hypothesis is consistent with any reciprocal movement between the European craton (or more precisely of its Iberian annex) and the African craton, as is strongly suggested by new data on the opening of the Atlantic.

Others interpret the arcuate structure as having been formed in late Neogene age, when Africa moved toward Europe. The internal zones of the Betic would thus have been displaced to the west by a movement that was dextral, in relation to Spain, along the boundary between the internal and external Betic zones (Fig. 3), while the internal zones of the Rif were displaced along the Nekor fracture separating the Rif from the Algerian chains.

This hypothesis is supported by the fact that the contact between the internal and external Betic zones is indeed the line of a major strike-slip fault. Furthermore, the external Betic zones show no curvature at their western end and thus cannot be easily linked with North Africa. The allochthonous flysch that envelops the Gibraltar arc did not exist in the Betic sector before the Burdigalian (Miocene). They were emplaced at that time following a late-phase gravitational sliding, immediately prior to the shearing which formed the "Alboran block" comprising the Betic and Rif internal zones.

\section{"Neotectonic" Arcs of Tyrrhenian and Aegean Seas}

The Aegean arc (Fig. 3) is a curious structure among the younger chains of the eastern Mediterranean, and contrasts with sectors (such as the internal Hellenic zones) that have been closed since the Upper Jurassic. The "Alpine" structures of the Hellenides resulted from the subduction process that is continuing even at present, indicating that this region of the eastern Mediterranean is a relic of the Tethyan oceanic crust still not completely resorbed.

Three significant features are recognizable: (1) a deep trench (the Hellenic trench) reminiscent of the Circum-Pacific trenches; (2) an external sedimentary arc running from the Pelopponese to southern Turkey through Cyprus, Crete and Rhodes, containing detritus derived from the external Hellenic zones and not from sedimentary accretion above the subduction zone; and (3) an internal volcanic arc extending from the Saronic gulf to the Turkish coast, marked by island volcanoes of Poros, Melos, Santorini (Thera) and Nisiros.

The Aegean thus takes on the appearance of a nascent marginal sea: even the emergence of oceanic crust and the distribution of earthquakes in the Aegean are consistent with the model.

Difficulties arise from the fact that the data currently available on the crust of the eastern Mediterranean are somewhat contradictory. Some facts suggest that the Mediterranean crust is more continental than oceanic, implying possibly that the Aegean subduction is nearly complete (with all the oceanic crust having been absorbed), and that the African continental margin now reaches to the edge of the Hellenic trench. The Tyrrhenian arc is somewhat similar.

The Sicily-Calabria arc outlines a subduction zone with westward dip and peri-Tyrrhenian vergence which functions as a sedimentary arc, but again with detritus derived from the Calabrian segment of the externides. This interpretation is in agreement with the distribution of deep-seated earthquakes in the Tyrrhenian sea, which itself has the appearance of a marginal basin. The line of the volcanic arc is traced by the volcanoes of the Aeolian islands and their submarine homologues.

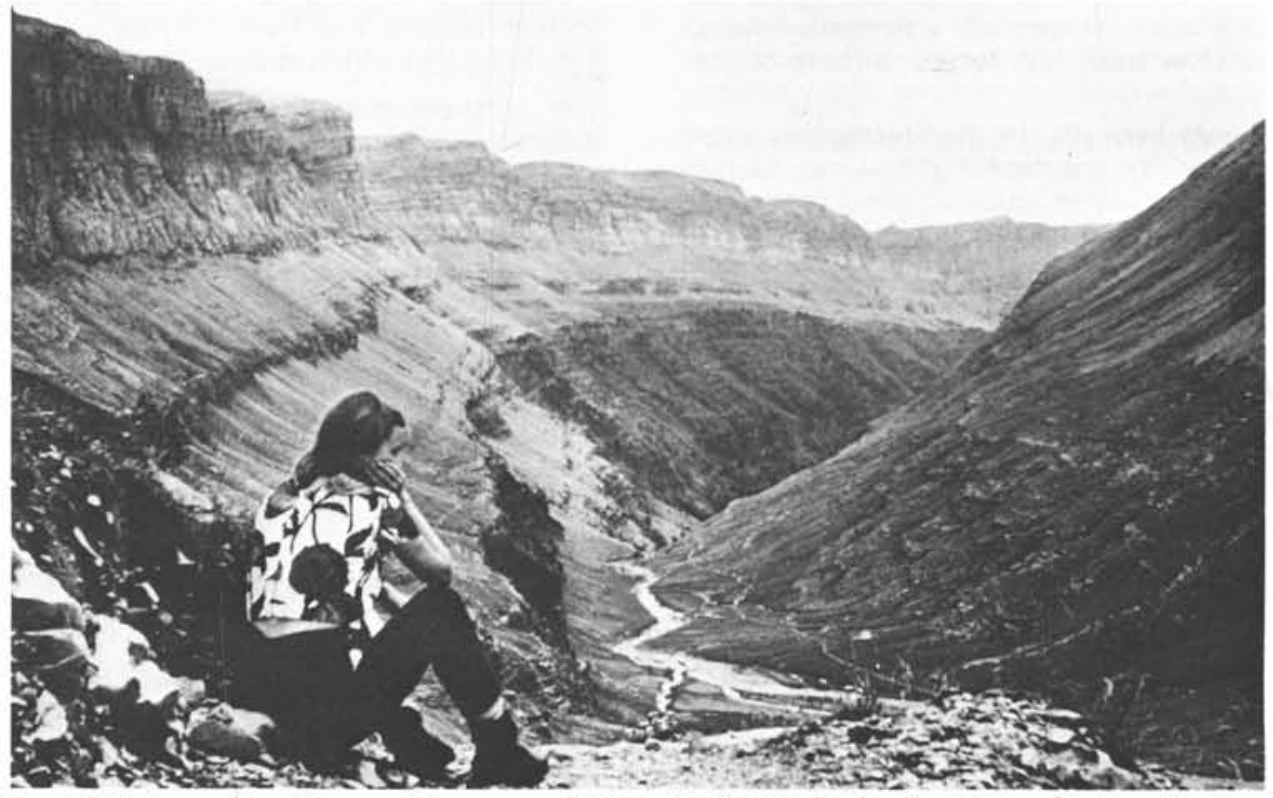

View SW down the Canon d'Arrazas, Ordesa National Park, Pyrenees, Spain: strata of Upper Cretaceous to Eocene age, forming part of the Mont Perdu nappe. (Photo courtesy W.C. Morgan)

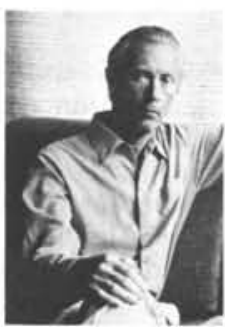

EPISODES, Vol. 1980, No. 1
ABOUT THE AUTHOR: Professor of Geology at the University of Grenoble in France, and Chairman of the Alpine Geology Institute, which is associated with the CNRS, Jacques B. Debelmas is convenor at the 26th IGC of the Colloquia on the geology of Alpine chains descended from the Tethys. His main research interests pertain to the geology of the French Occidental Alps and their connections with other European Alpine chains (Ligurian, Central and Eastern Alps, Carpathians, Appennines). 